\title{
COLLISIONS IN LOCAL LAWMAKING
}

\author{
Yana Lenher, \\ Head of the Department of Law, \\ Lutsk National Technical University, \\ Doctor of Juridical Science, Full professor, \\ orcid.org/0000-0003-2666-9709
} Scopus ID: https://www.scopus.com/authid/detail.uri?authorId=57216524932

ResearcherID: https://publons.com/researcher/3118536/lenher-yana/ lenger.yana303@gmail.com

\section{Summary}

The study is devoted to clarifying the problem of existing collisions in local lawmaking, which allowed to substantiate the common understanding of this problem, as well as to identify new theoretical and applied conclusions and positions related to the need to resolve collisions in local lawmaking, their specifics and special characteristics. It is established that the country has adopted and operates a large number of regulations, many of which contradict each other, have internal inconsistencies and inconsistencies. Legal science and practice face the task of in-depth analysis of the causes of municipal legal collisions, finding ways to prevent and resolve them. It is pointed out that the emergence and increasing severity of conflicts in local lawmaking in most cases due to incomplete legal regulation of public relations, violation of the rules of legal technique in the adoption of local acts, insufficiently effective ways to prevent and resolve the latter. In addition, it is established that the method of settling and resolving local conflicts through the prism of legislative establishment of the priority of application of the norm and act is the most clear and effective.

In the course of the research the systematic analysis of views on the collisions in law in general is carried out, the basic signs of the conflict in local law-making, its place among the specified categories in the plane are defined; analysis of the process of evolution of the social contradiction into a legal one with the subsequent transformation into a collision and a gap; legal conflict is defined as a subjective-objective phenomenon of legal reality. Among the existing large number of classifications of legal conflicts are local-legal, which are legal contradictions that arise due to subjective and objective reasons and errors in the exercise of powers to resolve the population directly and (or) through local governments, local issues, which is manifested in the adoption of regulations of local governments and their officials. Based on the analysis, the characteristic features of local-legal conflict are determined, which are detailed by the specified provisions on the connection of partial and general, manifestation in various forms and types, depending on the specifics of causes and solutions, local self-government issues of local significance and the emergence of the implementation of powers and the adoption of relevant municipal legal acts of local governments and their officials, with its own specific set of elements of the resolution mechanism.

Key words: conflict in law, legal contradiction, local-legal collision, mechanism for resolving local collisions, local act, local rule-making. 


\section{Introduction}

No matter how perfect the modern legislation with a high degree of regulation of public relations, it still from time to time there are contradictions and inaccuracies, which call the term "collision». Recently, the problem of presence of the lattest has become important in local acts during the implementation of local lawmaking. Appearing local legal collisions are marked by their severity and lead to uncertainty and inconsistency in the regulation of social relations of local importance. The growing severity of collisions in local acts is due to a number of reasons, including incomplete legal regulation of public relations, and violation of the rules of legal technique in the adoption of relevant acts, and the lack of effective ways to prevent such. All these determine the need to analyze the causes of collisions in local acts, finding out the ways to prevent and resolve them.

The current method of resolving local collisions by establishing norms in the legislation that determine the conditions of application of the act in case of contradictory regulation of the same social relations, unfortunately, was not properly reflected in the law-making process. Therefore, due to the need to develop general and special conflict procedures for the detection and resolution of local collisions this area of research is particularly relevant. The purpose of the research is to carry out constitutional and legal analysis of collisions in local lawmaking, their place among other legal phenomena, to study the causes of their occurrence, in particular those that are the most typical of the local act, as well as to identify effective elements of their resolution mechanism. their prevention, detection and full-fledged overcoming. The purpose of the study is achieved by solving the following tasks: the study of the concept of legal collision, its features and characteristics; identification of collision factors in local lawmaking; define the concept of local-legal collision, reveal its main features and specific features; describe the basic principles of conflict resolution in local lawmaking.

The methodological basis of the research were general methods of scientific knowledge, namely dialectical, analysis and synthesis, structural-logical, logical-semantic and formal-logical. Besides, the study is characterized by the methods used in legal science: comparative law and formal dogmatic. Thanks to the dialectical method it was possible to study the nature of legal collision as a legal phenomenon, to determine its main features and specific features. The dialectical method was widely used to determine the general rules of prevention, avoidance and elimination of conflicts in local lawmaking. The logical-semantic method is used to deepen the general conceptual and definitive apparatus.

The degree of scientific development of the topic. In the science of constitutional and municipal law, the problem of legal collisions was regarded to only in a theoretical and constitutional context. At the general theoretical level, legal collisions were considered by: A.M. Kolodii, O.Yu. Buiakov, V.V. Denysenko, M.M. Korkunov, L.A. Morozova, I.A. Pokrovskyi, V.I. Savin, S.S. Alekseiev, V.S. Nerseiants, I.M. Starodubtseva, Ye.V. Sukhov, N.I. Matuzov, O.F. Skakun, S.V. Bobrovnyk, O.V. Moskaliuk, Yu.M. Bysaha, O.Ya. Rohach, Ya.O. Berzaniuk. The study of contradictions in law, legal conflicts, as well as collisions in laws were examined by the following scholars: V.H. Kartashov, O.V. Boikov, M.I. Brun, M.M. Varlomova, M.O. Baimuratov, N.A. Vlasenko, O.V. Dmytriiev, V.N. Kudriavtsev, O.V. Batanov, V.L. Fedorenko, V.I. Bordeniuk, P.M. Liubchenko, H.V. Padalko, I.V. Drobush, A.A. Tile, S.V. Bobrovnyk, O.V. Skrypniuk, N.V. Mishyna, O.V. Sovhyria, Yu.A. Tykhomyrov, Yu.S. Semshuchenko, M.I. Koziubra, etc.

\section{Presenting main material.}

Defining local collision as a contradiction in the relations appearing during the exercise by the territorial community of its right to resolve issues of local importance both independently and through local authorities, as well as in their interaction with public authorities, it should be noted that the latter are extremely heterogeneous by their structure. The most significant and valuable of them are those that arise between local legal and (or) law enforcement acts. This provision is explained by the fact that the contradictions that arise on the basis of mutually exclusive regulations and law enforcement local legal acts are a prerequisite for the emergence of new social contradictions of local importance, strengthen modern relatively stable social relations and lead to violations of legal regulation in general. 
In order to be able to fully respond to the state of affairs with the presence of contradictions, it is necessary to reasonably identify the causes and main factors that cause contradictions and instability of social relations in the state. It is a well-known fact that contradictions in law act only as a part of social contradictions, but are the most significant and significant part of these contradictions. This is due to the influence that has the right to develop social relations.

Defining contradictions in normative-legal acts as contradictions in the public relations regulated by norms of law (Bobrovnyk, 2012, p.35), it should be said that they are extremely heterogeneous in their structure. The most significant and significant contradictions in law are legal conflicts - contradictions that arise between legal and (or) law enforcement acts (Bobrovnik, 2012, p. 40). This provision is explained by the fact that contradictions arising on the basis of mutually exclusive regulations and law enforcement acts are in themselves a prerequisite for the emergence of new social contradictions that exacerbate and reinforce the instability of social relations (Zaiets, 2005, p. 88). Due to the urgent need to create an effective legal mechanism to prevent and overcome local legal conflicts, it is necessary to study carefully the causes and preconditions of contradictions in law to understand not only the consequences but also the very basis that caused to these legal contradictions. At the same time to create a real mechanism for overcoming local legal conflicts it is necessary, first of all, to create a regulatory framework that allows to resolve legal conflicts within the legal field (Lenher, 2017, p. 28).

To create a regime to prevent local legal conflicts the principle of ensuring the supremacy of the constitution and the law, observance of legal priorities, inevitability of responsibility for violation of the rule of law, widespread use of procedures for reaching agreement and social harmony and the formation of a high legal culture play an important role.

During the research it was identified that in order to maintain a single coherent legal system it is necessary to create clear legal mechanisms governing the overcoming legal contradictions The creation of these mechanisms is a complex and multifaceted problem that cannot be clarified without studying, first of all, the causes of these contradictions as phenomena of legal reality.

The study identified that in order to maintain a single, integrated legal system, it is necessary to create clear legal mechanisms governing the overcoming of legal contradictions. The creation of these mechanisms is a complex and multifaceted problem that cannot be clarified without studying, first of all, the causes of these contradictions, as phenomena of legal reality.

At the current stage of legislative development there is a large number of legal acts, as well as actively developing local lawmaking. Most often in the process of lawmaking and law enforcement there are legal conflicts. They are contradictions between legal norms, between legal acts (Koziubra, 2012, p. 33).

Numerous conflicts of legal acts indicate broken links, especially within the system of legislation which indicates the problems of its development and effectiveness.

The causes of legal conflicts are laid both in the law-making process and in the law enforcement activities. Currently, the prevailing reasons are caused by shortcomings in the application of legal rules, methods, techniques which leads to numerous local collisions. In turn, as practice shows, the adoption of a large number of regulations leads to frequent changes to them which contributes to legal inconsistencies.

Most often, the proper interaction of public authorities with each other, as well as between public and local authorities is complicated by emerging legal collisions in the field of delimitation of their competence. First of all, a complete and detailed analysis of the causes of local legal collisionts allows you to apply correctly one or another way to resolve these contradictions.

General rules for resolving legal collisions are important in resolving local legal conflicts. They are that in case of contradiction of normative-legal acts of different legal force, the act having higher legal force is applied (Lysiutkyn, 2001, p. 75); in case of contradiction between general and special normative legal acts the special normative legal act is applied; in case of contradiction between the normative legal act adopted earlier and the normative legal act adopted later, the normative legal act adopted 
later shall apply on the same issue; laws and other legal acts should not contradict the Basic Law of the state (Constitutional Court Decision, 2009). General rules for resolving legal collisions play an important role in overcoming and resolving them.

Currently, the legislation needs to resolve legal collisions in a timely manner. Overcoming and eliminating local legal collisions is achieved through effective ways to resolve the lattest. Ways to resolve local legal conflicts are aimed at identifying, overcoming and eliminating the latter. Monitoring is very important as the way to identify legal collisions in the law-making process and in law enforcement activities (Shemshuchenko, 1996, p. 10). Such monitoring functions as observation, collection, study, analysis of legal acts, drawing up plans and programs of normative design activities, legal forecasts, allow timely detection of contradictions (inconsistencies) between legal acts and apply the most effective ways to resolve them.

Legal conflicts can be detected by maintaining a register of regulations.

The prevention is aimed to debar legal collisions and, in our opinion, includes conducting a preliminary legal examination of regulations and their coordination; drawing up plans and programs of bills, legal forecasts, etc.

With the help of effective ways to resolve all possible legal collisionts in public law their timely overcoming is ensured. The latter consists in the existence of conflict rules that establish: the procedure for applying legal acts and norms in case of their inconsistency; conciliation procedures; temporary or special regimes; appeals against regulations in courts of general and special jurisdiction.

The nature of the development of the legal system today has objectively determined the development of collision of laws, which primarily contributes to the resolution of legal collisions. The law of collision is a complex legal institution that combines the rules of different branches of law (constitutional, administrative, financial, municipal, etc.), performs a function aimed at streamlining the legal system to overcome legal conflicts, providing ways to prevent and resolve them. Ensuring the hierarchy of regulations, legal monitoring, widespread use of conciliation procedures, the creation and application of con- flict rules - these are the main guidelines for the development of legislation. In turn, the active and comprehensive use of methods aimed at preventing, detecting, overcoming and eliminating legal conflicts, will maintain the stability of the legal system of the country. The legal mechanism for resolving legal collisions is the system of interconnected special legal means by which legal influence on legal conflicts is exercised in order to resolve them. Elements of the mechanism for resolving legal collisions in the field of local lawmaking are the principles of conflict resolution, procedures for their prevention and resolution. The principles of resolving legal collisions in the field of local lawmaking are the basic principles that determine the resolution of contradictions in the legal system that arise when the population resolves issues directly and (or) through local governments.

Legal collisions in the field of local lawmaking have the following features:

1) dependence on the legal system of the country and, accordingly, to the legislative regulation of issues of local importance;

2) the sphere of public relations in which legal collisions arise - the issues of local importance and state powers delegated to local authorities;

3) most often legal collisions arise in the regulation of the following typical issues: setting tariffs for various services, land management, municipal land control, participation in the prevention and elimination of the consequences of emergencies, ownership, use and disposal of municipal property.

Legal collisions in the field of local lawmaking are divided into groups: legal collisions in lawmaking (in local legal acts) and legal collisions in law enforcement (between elements of the legal system relating to the activities of local authorities and arise in resolving issues of local importance) (Rybikova, 2008, p. 75).

The main patterns of legal collisions in the field of local lawmaking are:

1) the absence of legally enshrined in regulations strategy and forecast of socio-economic development of the relevant territorial communities and administrative-territorial unit;

2) disregard to some extent the specifics of a particular administrative-territorial unit in the adoption of regulations; 
3) insufficient development of the mechanism of interaction between state authorities and local authorities;

4) dependence of legal conflicts on the qualification of subjects at the level of local self-government (exceeding the powers of local self-government bodies, violation of the rules of legal technique).

The institute of resolving local-legal collisions has features that are inherent in complex inter-sectoral institutions (homogeneity of factual content, legal unity (complexity) of norms of different branches of law, allocation of sub-institutions in the structure of the institute).

Legal relations that arise in the process of resolving legal collisions in the field of local lawmaking are a special type of social relations. They are characterized by features that distinguish them from other legal relations, and have a special purpose: to prevent and resolve inconsistencies in the legal system that arise when the population resolves directly and (or) through local authorities issues of local importance.

The content of the mechanism for resolving local legal collisions is the rights and responsibilities of the subjects of legal relations, which are implemented in law enforcement activities (Lenher, 2017, p. 24). The powers of the subjects of legal relations are different. Some of them have broad rights to identify and resolve legal conflicts in the field of local lawmaking, while the activities of others - aimed only at resolving collisions, others - have only the right to go to court to resolve legal collisions in local acts.

The content of the mechanism for resolving collisions in the field of local lawmaking includes methods of identifying and resolving collisions, based on the respective powers of state and local authorities.

Based on a theoretical study of legal regulation and legal relations that arise in resolving legal collisions in the field of local lawmaking, the ways to improve legislation and law enforcement are made.

The following points are offered to improve the legal institution of resolving legal collisions in the field of local lawmaking, Firstly, to enshrine in law the temporal collisial principle and the principle of priority of authority. The temporal collisial principle establishes the priority of a legal norm adopted later, that is in case of con- flict between legal norms (or acts) that have the same legal force, but adopted at different times, the norm adopted later has priority.

When conducting a legal examination, take into account that the main signs of violations of the local legal act of legislation are: a) the lack of legal grounds necessary for the issuance of a local act; b) incorrect choice of the law applied at adoption of the local act, issue of the local act on execution of the canceled law; c) adoption of an act by a body within whose competence it is not included, or publication in excess of the powers granted to this body; d) violation of the procedure for adoption and entry into force of a local act.

To prevent legal collisions in the field of local lawmaking, it is recommended to use coordination more widely as coordination of public authorities at different levels (decisions and actions, action plans, forms of training of civil and municipal officials).

Implementation of the above proposals to improve legislation and law enforcement will prevent local legal conflicts, increase the effectiveness of the legal mechanism for resolving legal collisions, develop cooperation between public authorities at various levels.

\section{Ways to resolve local conflicts.}

Methods of resolving legal conflicts that arise between legal acts can be considered appropriate such as the interpretation of law. In turn, interpretation is a complex process, as a result of which an accurate and complete definition of the content of the provision enshrined in the legal act is given. The process of interpretation is that the subject who interprets, first realizes the content of the legal act for himself, determines the direction of its activities, and then in order to uniformly understand and apply the legal act explains its meaning and content to other stakeholders. Such an explanation objectifies the results of the clarification. Objectification-related objectification finds its expression in writing in the form of an official document, legal act, or orally in the form of advice or recommendation.

Prevention - used at the stage of preparation, adoption and implementation of laws. Preventive measures for conflicts: 1) forecasting and planning of rule-making activities; 2) im- 
provement of legislative technique; 3) conducting legal examination of draft regulations (coordinating them with the system of existing acts); 4) systematization of legislation.

Elimination - complete release from conflicts in the process of legislative activity, their elimination. Ways to eliminate conflicts: 1) cancellation of one (or several) conflict acts; 2 ) making changes to the legal act; 3) adoption of a new norm (or normative legal act); 4) judicial review (recognition by a court - the Constitutional Court and administrative courts - of a normative act as not corresponding to an act of higher legal force).

Overcoming - temporary resolution of conflicts with the application of a certain legal norm, but without the final removal of contradictions between them (the conflict between the norms does not disappear). Ways to overcome conflicts: 1) the use of conflict rules (rules-arbitrators); 2) interpretation of legislative acts, especially when the choice between norms cannot be made on the basis of conflicting norms; 3) application of general rules for overcoming conflicts: temporal (temporal), hierarchical (subordination), semantic, mixed, types of conflicts in legislation and general rules for overcoming them.

Local conflicts are resolved through interpretive activities. Thus, bringing clarity to the content of the interpreted norm, the act of interpretation thus resolves the legal conflict in the understanding of law, pointing to the only correct version of its understanding and appropriate application. A special role in the process of overcoming legal conflicts through the interpretation of the rule of law belongs to the Constitutional Court of Ukraine. The specificity of constitutional proceedings as a means of resolving legal conflicts is that, eliminating conflict rules, the body of interpretation does not create an independent rule of law. In our opinion, the interpretation of a normative legal act is not a process of creating independent norms, and the provisions that arise during the interpretation are inseparable from the norms of the Basic Law and other acts, we can say that they are a kind of continuation. The resolution of a legal conflict occurs by depriving a norm recognized as unconstitutional of legal force. This provision is enshrined in the Constitution of Ukraine.
However, it should be noted that, as a way of overcoming a legal conflict, interpretation does not guarantee a complete resolution of the contradictions.

Even in the Constitutional Court, which is called upon to interpret the relevant legal norms and acts, there is no unity of opinion, and some of its judges formally declare their special position on certain issues. Thus, there is inevitably a subjective point in the interpretation of law.

Legal conflicts can also be resolved through the adoption of a «new» act instead of a contradictory one, or the abolition of one of the contradictory ones.

For example, you can appeal against legal acts of public authorities by applying to the body or official who has the right to cancel or suspend the issued act.

In contrast to the repeal of a legal act, the suspension of a legal act provides for the need to apply to the court of the body or official who suspended the act, in order to definitively determine the fate of this legal act.

An effective way to eliminate local conflicts can also be considered to make changes or clarifications or additions to the legal act. Currently, there is a trend of frequent and large-scale changes in legislation on the separation of powers between public authorities and local governments. It should be noted that amendments to the laws on amendments become a permanent legislative practice, which significantly complicates law enforcement practice.

\section{Conclusions.}

The causes of legal conflicts are laid both in the law-making process and in law enforcement activities. Currently, the prevailing reasons are caused by shortcomings in the application of rules, methods, techniques of legal techniques, which leads to numerous local conflicts. In turn, as practice shows, the adoption of a large number of regulations leads to frequent changes in them, which contributes to legal inconsistencies. Most often, the proper interaction of public authorities with each other, as well as between public authorities and local governments is complicated by emerging legal conflicts in the field of delimitation of their competence. First of all, a complete and detailed analysis of the causes of legal conflicts in local lawmaking allows you to 
correctly apply one or another way of resolving these contradictions.

The general rules for resolving legal conflicts are important in resolving local conflicts. They consist in the fact that: in case of contradiction of normative-legal acts of different legal force, the act having higher legal force is applied; in case of contradiction between general and special normative legal acts the special normative legal act is applied; in case of contradiction between the normative legal act adopted earlier and the normative legal act adopted later, the normative legal act adopted later shall apply on the same issue; laws and other legal acts must not contradict the Constitution. General rules for resolving local conflicts play an important role in overcoming and resolving them.

Currently, the legislation needs to resolve legal conflicts in a timely manner. Overcoming and eliminating local collisions is achieved through effective ways to resolve such. Ways to resolve local conflicts are aimed at identifying, overcoming and eliminating the latter.

Monitoring is of particular importance as a way to identify legal conflicts in the process of local lawmaking and law enforcement. Such monitoring functions as observation, collection, study, analysis of legal acts, drawing up plans and programs of normative design activities, legal forecasts, allow timely detection of contradictions (inconsistencies) between legal acts and apply the most effective ways to resolve them.

Also in conclusion, it should be noted that more attention should be paid to the prevention of legal conflicts in local lawmaking. Prevention is aimed at preventing legal conflicts and, in our opinion, includes: conducting a preliminary legal examination of regulations and their coordination; drawing up plans and programs of bills, legal forecasts, etc.

With the help of effective ways to resolve all possible legal conflicts in public law, their timely overcoming is ensured. The latter consists in the existence of conflict rules that establish: the procedure for applying legal acts and norms in case of their inconsistency; conciliation procedures; temporary or special regimes; appeals against regulations in courts of general and special jurisdiction.

\section{Bibliography:}

1. Бобровник, С. В. (2012). Конфликтные правоотношения: понятие, природа, структура, сущность. Вестник
Института законодательства Республики Казахстан, 2 (26), С. 33-44.

2. Заєць, А. Г. (2005). Тлумачення норм права - спеціальний вид юридичної діяльності. Держава і право: зб. наук. пр. Київ, 28, С. 85-89.

3. Козюбра, М. (2012). Верховенство права і Україна. Право України, 1-2, С. 30-43.

4. Ленгер, Я. І. (2017). Закономірності вирішення правових колізій в муніципальному праві. Науковий вісник публічного і приватного права, 1, С. 22-25.

5. Ленгер, Я. І. (2017). Ієрархічний та змістовний принципи вирішення правових колізій в муніципально-правових актах. Вісник Херсонського університеmy. 2, С. 23-29.

6. Лисюткин, А. Б. (2001). Юридическая техника и правовые ошибки. Государство и право. 11, С. 72-77.

7. Положення про державну реєстрацію нормативно-правових актів міністерств та інших органів виконавчої влади (1992): постанова Кабінету Міністрів України о. 731. Урядовий кур'єр. 1993, 25-26. URL: http://zakon3.rada.gov.ua/laws/show/731-92$\% \mathrm{D} 0 \% \mathrm{BF}$

8. Про затвердження Методичних рекомендацій щодо проведення експертизи проектів нормативно-правових актів на наявність корупціогенних норм (2010): наказ Міністерства юстиції України № 1380/5. URL: http://zakon3.rada.gov.ua/laws/show/ en/v3099323-11

9. Рибікова, Г. В. (2008). Види правової експертизи нормативно-правових актів України. Юридичний вісник. 2008.4 (9), С. 74-77.

10. Рішення Конституційного Суду України у справі за конституційним поданням Харківської міської ради щодо офіційного тлумачення положень частини другої статmі 19, статmі 144 Конституиії україни, статті 25, частини чотирнадиятої статті 46, частин першої, десятої статті 59 Закону України «Про місиеве самоврядування в Україні» (2009) (справа про скасування актів органів місцевого самоврядування) No 7-рп/2009. URL:http://zakon2.rada.gov. ua/laws/show/v007p710-09.

11. Шемшученко, Ю. С. (1996). Теоретичні засади подолання колізій у законодавстві України. Колізії у законодавстві України: проблеми теорії і практики: матеріали міжнар. наук.-практ. конф. (м. Київ, 23-24 жовт. 1995 р.). Київ: Генеза, С. 7-11.

\section{Reference:}

1. Bobrovnyk, S. V. (2012). Konfliktni pravovidnosyny: ponyattya, pryroda, struktura, sutnist' [Conflicting legal relations: concept, nature, structure, essence]. 
Visnyk Instytutu zakonodavstva Respubliky Kazakhstan, 2 (26), 33-44. [ in Russian].

2. Zayets', A. H. (2005). Tlumachennya norm prava - spetsial'nyy vyd yurydychnoyi diyal'nosti [Interpretation of law - a special type of legal activity]. Derzhava i pravo, 28, 85-89.[ in Ukrainian].

3. Kozyubra, M. (2012). Verkhovenstvo prava i Ukrayina [Rule of law and Ukraine]. Pravo Ukrayiny, 1-2, 30-43.[ in Ukrainian].

4. Lenher, Ya. I. (2017). Zakonomirnosti vyrishennya pravovykh koliziy v munitsypal'nomu pravi [Regularities of solving legal collisions in municipal law]. Naukovyy visnyk publichnoho i pryvatnoho prava, 1, 22-25.[in Ukrainian].

5. Lenher, Ya. I. (2017). lyerarkhichnyy ta zmistovnyy pryntsypy vyrishennya pravovykh koliziy $\mathrm{v}$ munitsypal'no-pravovykh aktakh [Hierarchical and substantive principles of solving legal collisions in municipal legal acts]. Visnyk Khersons'koho universytetu, 2, 23-29.[in Ukrainian].

6. Lysyutkyn A. B. (2001). Yurydycheskaya tekhnyka y pravovye oshybky [Legal technique and legal errors]. Hosudarstvo y pravo, 11, 72-77.[ in Russian]

7. Polozhennya pro derzhavnu reyestratsiyu normatyvnopravovykh aktiv ministerstv ta inshykh orhaniv vykonavchoyi vlady [About the statement of Methodical recommendations concerning carrying out examination of projects of regulatory legal acts for existence of corruptioncausing norms]: postanova Kabinetu Ministriv Ukrayiny No 731. Available from: URL: http://zakon3.rada.gov. ua/laws/show/731-92-\%D0\%BF [in Ukrainian].

8. Pro zatverdzhennya Metodychnykh rekomendatsiy shchodo provedennya ekspertyzy proektiv normatyvnopravovykh aktiv na nayavnist' koruptsiohennykh norm
[About the statement of Methodical recommendations concerning carrying out examination of projects of regulatory legal acts for existence of corruption-causing norms] (2010): nakaz Ministerstva yustytsiyi Ukrayiny No 1380/5. URL: http://zakon3.rada.gov.ua/laws/ show/en/v3099323-11 [ in Ukrainian].

9. Rybikova, H. V. (2008). Vydy pravovoyi ekspertyzy normatyvno-pravovykh aktiv Ukrayiny [Types of legal examination of normative legal acts of Ukraine]. Yurydychnyy visnyk, 4 (9), 74-77.[ in Ukrainian].

10. Rishennya Konstytutsiynoho Sudu Ukrayiny u spravi za konstytutsiynym podannyam Kharkivs'koyi mis'koyi rady shchodo ofitsiynoho tlumachennya polozhen' chastyny druhoyi statti 19, statti 144 Konstytutsiyi Ukrayiny, statti 25, chastyny chotyrnadtsyatoyi statti 46, chastyn pershoyi, desyatoyi statti 59 Zakonu Ukrayiny «Pro mistseve samovryaduvannya v Ukrayini» [Decision of the Constitutional Court of Ukraine in the case on the constitutional petition of the Kharkiv City Council regarding the official interpretation of the provisions of part two of Article 19, Article 144 of the Constitution of Ukraine, Article 25, part fourteen of Article 46, parts one, ten of Article 59 of the Law of Ukraine "On Local SelfGovernment in Ukraine»] (2009) (sprava pro skasuvannya aktiv orhaniv mistsevoho samovryaduvannya) No 7-rp/2009. Available from: http://zakon2.rada.gov.ua/ laws/show/v007p710-09.[ in Ukrainian ].

11. Shemchuchenko, Yu. S. (1996). Teoretychni zasady podolannya koliziy u zakonodavstvi Ukrayiny [Theoretical principles of overcoming collisions in the legislation of Ukraine]. Koliziyi u zakonodavstvi Ukrayiny: problemy teoriyi i praktyky: materialy mizhnar. nauk. prakt. konf (pp. 7-11). Kyiv: Genesis[ in Ukrainian].

\section{КОЛІЗІЇ В ЛОКАЛЬНІЙ ПРАВОТВОРЧОСТІ}

\section{Яна Ленгер,} завідувач кафедри права Луцького національного технічного університету, доктор юридичних наук, професор, orcid.org/0000-0003-2666-9709

Scopus ID:

https://www.scopus.com/authid/detail.uri?authorId=57216524932 ResearcherID: https://publons.com/researcher/3118536/lenher-yana/ lenger.yana303@gmail.com

\section{Анотація}

Дослідження присвячене з'ясуванню проблеми існування колізій в локальній правотворчості, що дало змогу обгрунтувати єдине розуміння вказаної проблеми, а також виокремити нові теоретичні та прикладні ви- 
сновки та положення, що пов'язані з необхідністю розвязання колізій в локальній правотворчості, їх специфіки та особливих характеристик. Встановлено, що в країні прийнято і діє велика кількість нормативно-правових актів, багато з яких суперечать один одному, мають внутрішні невідповідності і неузгодженості. Перед юридичною наукою і практикою стоїть завдання глибокого аналізу причин виникнення муніципально-правових колізій, пошук шляхів їх попередження та розвязання. Виокремлено, що виникнення і наростаюча гострота колізій в локальній правотворчості в більшості випадків обумовлюється неповнотою правового регулювання суспільних відносин, порушенням правил юридичної техніки при прийнятті локальних актів, недостатньо ефективними способами попередження та вирішення останніх. Крім того, встановлено, що метод врегулювання та вирішення локальних колізій через призму законодавчого встановлення пріоритетності застосування норми і акту є чи найбільш зрозумілим та ефективним.

В процесі дослідження здійснено системний аналіз поглядів на колізію в праві загалом, визначено основні ознаки колізії в локальній правотворчості, ії місце серед вказаних категорій в площині; аналіз процесу еволюції соціального протиріччя в правове з подальшою трансформацією в колізію та прогалину; визначено правову колізію як субєєктивно-обєктивне явище правової дійсності. Виокремлено серед наявної великої кількості класифікацій правових колізій локально-правові, котрі є правовим протиріччям, що виникає через суб'єктивні та обєєктивні причини та помилки під час реалізації повноважень з вирішення населенням безпосередньо і (або) через органи місцевого самоврядування питань місцевого значення, що проявляється при прийнятті нормативних актів органів місцевого самоврядування та їх посадових осіб. Визначено на основі аналізу характерні ознаки локально-правової колізії, котрі деталізуються вказаними положеннями про звязок часткового і загального, прояві у різноманітних формах та видах, залежно від специфіки причин виникнення та способів розвязання, в просторовому обмеженні сферою здійснення безпосередньо або через органи місцевого самоврядування питань місцевого значення та виникненні при реалізації повноважень та прийнятті відповідних муніципально-правових актів органів місцевого самоврядування та ї посадових осіб, з наявним власним специфічним набором елементів механізму розвязання.

Ключові слова: колізія в праві, правова суперечність, локально-правова колізія, механізм розвязання локальних колізій, локальний акт, локальна нормотворчість. 